\title{
Study of Frequency of the Palmaris Longus Muscle in Chilean Subjects
}

\author{
Estudio de la Frecuencia del Músculo Palmar Largo en Individuos Chilenos
}

"Nilton Alves; *Daysi Ramírez \& **Naira Figueiredo Deana

ALVES, N.; RAMÍREZ, D. \& DEANA, N. F. Study of frequency of the palmaris longus muscle in Chilean subjects. Int. J. Morphol., 29(2):485-489, 2011.

SUMMARY: The palmaris longus muscle (PLM) lies on the anterior region of the forearm, it is considered one of the most variable muscles in the human body, and its agenesis is the most frequent anatomic variation. The aim of this study was to evaluate the frequency of the PLM tendon in Chilean adults and also, to verify the agenesis symmetry according to sex. For this, we have analyzed the presence of the PLM tendon in 200 Chilean individuals, 114 female and 86 male. In this study, three different tests were used: Schaeffer's Test, Mishra's First Test and Thompson's Test. The obtained data were tabled and analyzed. It could be observed that $91 \%$ of the individuals had the PLM muscle tendon in at least one of the forearms and $80 \%$ in both forearms. The unilateral agenesis was found in $11 \%$ of the cases (5\% on the right side and $6 \%$ on the left side) and bilateral agenesis was found in $9 \%$ of cases. When analyzing the frequency of the muscular tendon according to sex, we could observe that the PLM is more commonly found in men (82.56\%) than in women (78.07\%) (p>0.05). Besides, we could observe that the agenesis is most frequent on the left side in women however, no significant statistical difference could be observed when the symmetry according to sex was analyzed $(\mathrm{p}>0.05)$.

KEY WORDS: Palmaris longus muscle; Anatomic variation; Agenesis.

\section{INTRODUCTION}

The palmaris longus muscle (PLM) lies in the anterior region of the forearm, has its origin at the epicondylus medialis of the humerus and inserts itself in the aponeurosis palmaris and into the distal part of the retinaculum musculorum flexorum. Its function is to tension the aponeurosis palmaris and it also works as an auxiliary flexor (Dângelo \& Fattini, 1983).

According to some authors, besides having a secondary function, the loss of this muscle would not cause any significant loss of strength (Lippert, 1996). According to Sebastin \& Lim (2006) the PLM experienced a filogenetic withdrawal with loss of function during human evolution and presented a gradual extinction. Besides, they claim that its absence would not cause a functional loss of the wrist and hand.

On the other hand, this muscle presents a great clinical relevance when used as a donator tendon in surgery techniques as the reconstruction of the hand (Wehbé, 1992; Park et al., 2010) and the plastic surgery to repair neck and head, cases in which we can obtain a satisfactory functional and aesthetic reconstruction (Ueda et al., 2007; Ozeri et al., 2009).

The PLM is considered one of the most variable muscles in the human body, its agenesis is considered the most frequent anatomical variation (Gray \& Goss, 1977). Some authors suggest that there is a relation between the prevalence of the PL agenesis and different ethnic groups (Reimann et al., 1944; Kapoor et al., 2008). The text-books report that the incidence of the agenesis is of $14 \%$ (Moore \& Agur, 1996), but a great diversity in the prevalence of this anatomic variation in different population has been reported. In a study with the Turk population, Ceyhan \& Mavt (1997) reported that $63.91 \%$ of the individuals presented PLM agenesis. However, Sebastin et al. found $4.6 \%$ of agenesis in Chinese, and Gangata (2009), when evaluating black individuals from African origin, observed that only $1.5 \%$ of the sample presented absence of PLM.

In this study, our aim was to verify the frequency of the PLM tendon in adult Chilean individuals, and, also, observe the agenesis symmetry according to sex.

\footnotetext{
* Departamento de Ciencias Básicas y Biomédicas. Facultad de Ciencias de la Salud, Universidad de Talca.

${ }^{* *}$ Kinesióloga - Brasil
} 


\section{MATERIAL AND METHOD}

In this work were examined 200 young Chilean adult of both sexes, leucoderm, 86 male and 114 female, with age varying from 17 to 32 years old. The sample included employees and students from the Medicine and Odontology courses from the Universidad de Talca, Chile.

The following three tests were used to accomplish the exams, on both of the forearms of all individuals, where the PLM tendons were visually observed and palpated by an examiner:

1- Schaeffer's Test: the examiner asks to the subject to accomplish the movement of thumb opponency, followed by wrist flexion (Schaeffer, 1909) (Fig. 1).

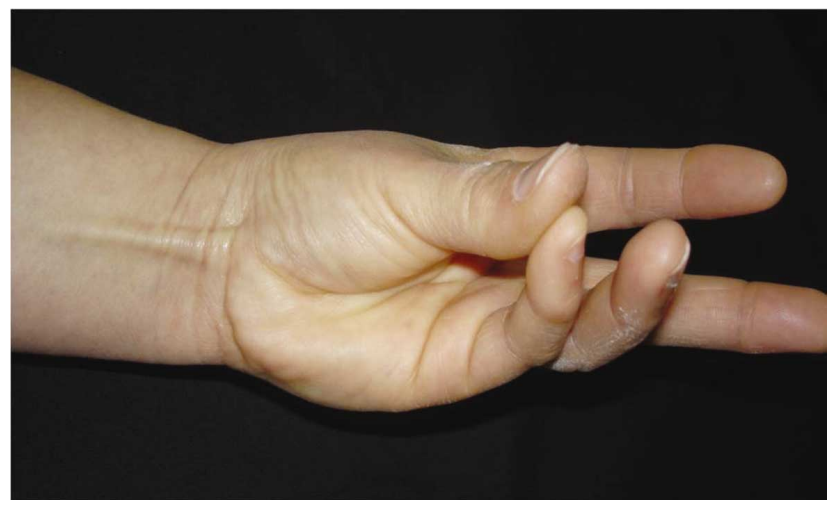

Fig. 1. Schaeffer's Test.

2. Mishra's First Test: the examiner hyperextends the metacarpophalangeal joints and asks the patient to flexion the wrist at the same time that he imposes some resistance against the movement (Mishra, 2001) (Fig. 2).

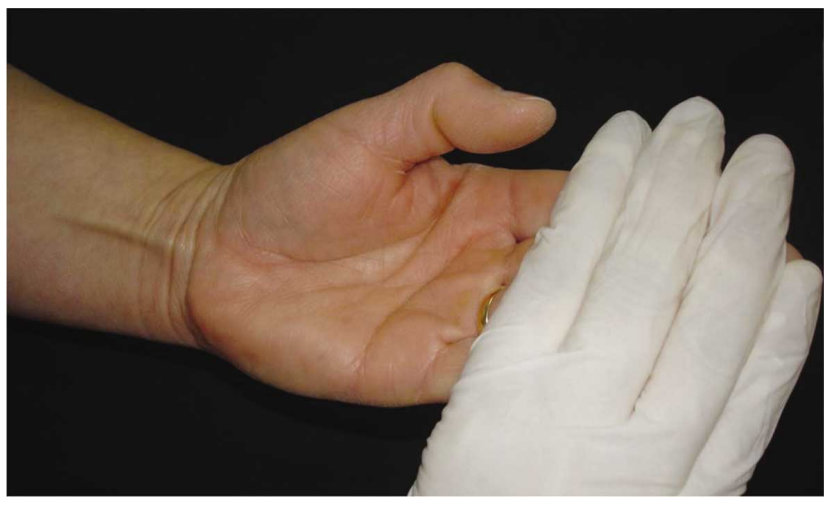

Fig. 2. Mishra’s first Test.

3. Thompson's Test: The patient makes a fist and then a flexion movement of the wrist, after that, he/she put his/her thumb over the other fingers (Thompson, 1921) (Fig. 3).

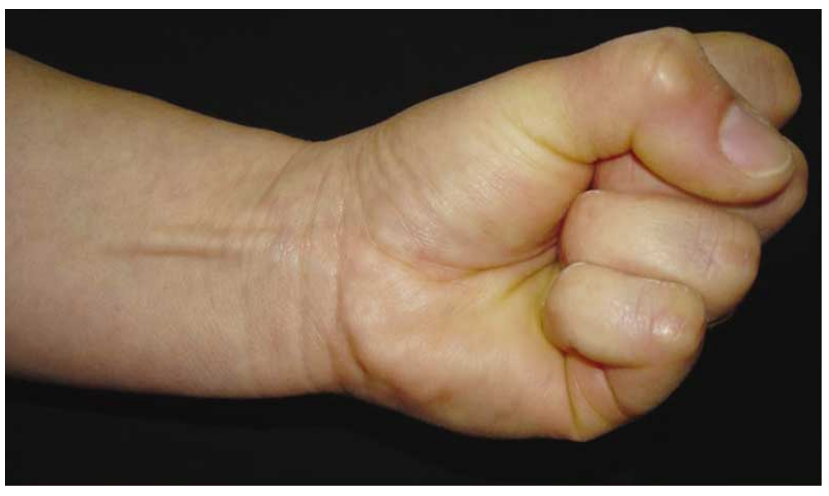

Fig. 3. Thompson's Test.

The PLM tendon was considered present in the cases where it could be visualized and palpated in at least one of the three tests, and it was considered absent when it could not be palpated in any of the tests. The obtained data were analyzed and tabled.

\section{RESULTS}

In this study, forearms of 200 individuals were analyzed (114 women and 86 men), with average age of 18.97 years old (DS \pm 2.06 years old). The average age of women was 18.81 years old (DS \pm 1.94 years old) and the average for men was 19.17 years old (DS \pm 2.19 years old).

Among the 200 subjects analyzed 182 (91\%) presented the PLM tendon in at least one of the forearms and $160(80 \%)$ presented it in both forearms. The unilateral agenesis was observed in $11 \%$ (5\% on the right side and 6\% on the left side) of the cases and the bilateral absence was reported in $9 \%$ of the cases. Therefore, the unilateral agenesis was more common than the bilateral one, however, there was no significant statistical difference ( $p>0.05)$ (Table I).

The total agenesis (unilateral and bilateral) was observed with a higher frequency in women, that is, among 114 women, 25 (21.93\%) presented agenesis, on the other hand, in the men sample, $\mathrm{n}=86$, only $15(17.44 \%)$ presented absence of the PLM tendon, however, there was no significant statistical difference ( $p>0.05)$. Among the 15 men who presented agenesis, $6(6.98 \%)$ were bilateral, and 9 $(10.46 \%)$ unilateral, $4(4.65 \%)$ on the right side and 5 $(5.81 \%)$ on the left side. Among the sample of 25 women with agenesis, $12(10.52 \%)$ presented bilateral agenesis, 13 
Table I. Percentage of absence of the palmaris longus muscle.

\begin{tabular}{crccc}
\hline Absent & Bilateral & Right Unilateral & Left Unilateral & Total \\
\hline Men & $6(3 \%)$ & $4(2 \%)$ & $5(2.5 \%)$ & $15(7.5 \%)$ \\
Women & $12(6 \%)$ & $6(3 \%)$ & $7(3.5 \%)$ & $25(12.5 \%)$ \\
\hline Total & $18(9 \%)$ & $10(5 \%)$ & $12(6 \%)$ & $40(20 \%)$
\end{tabular}

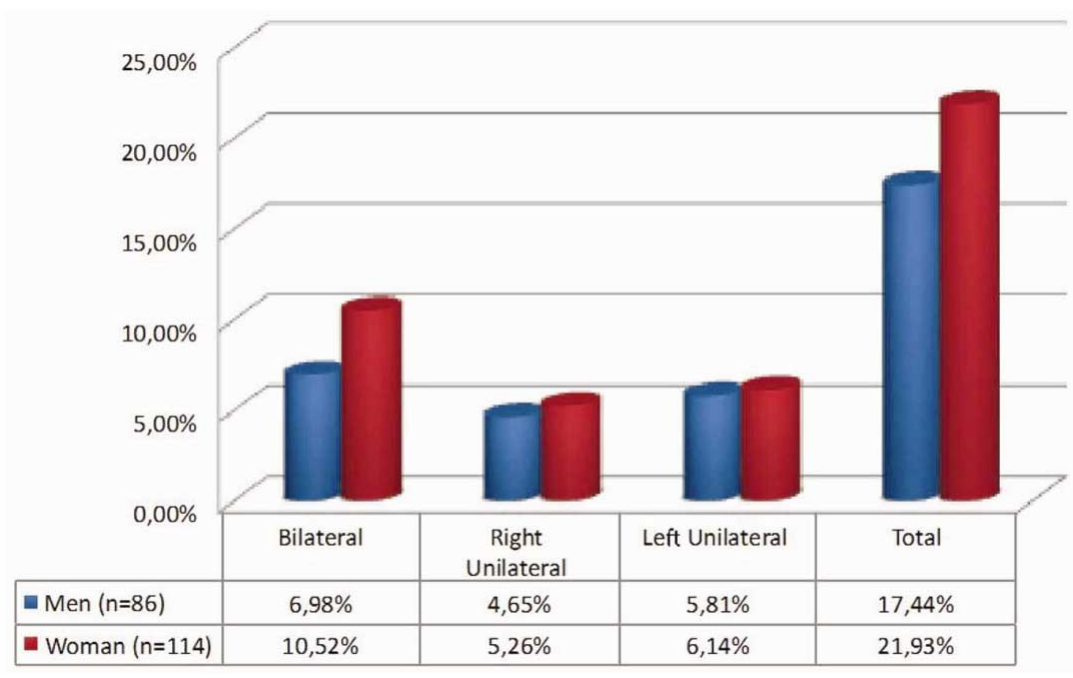

Fig. 4. Palmaris longus muscle absence according sex (\%).

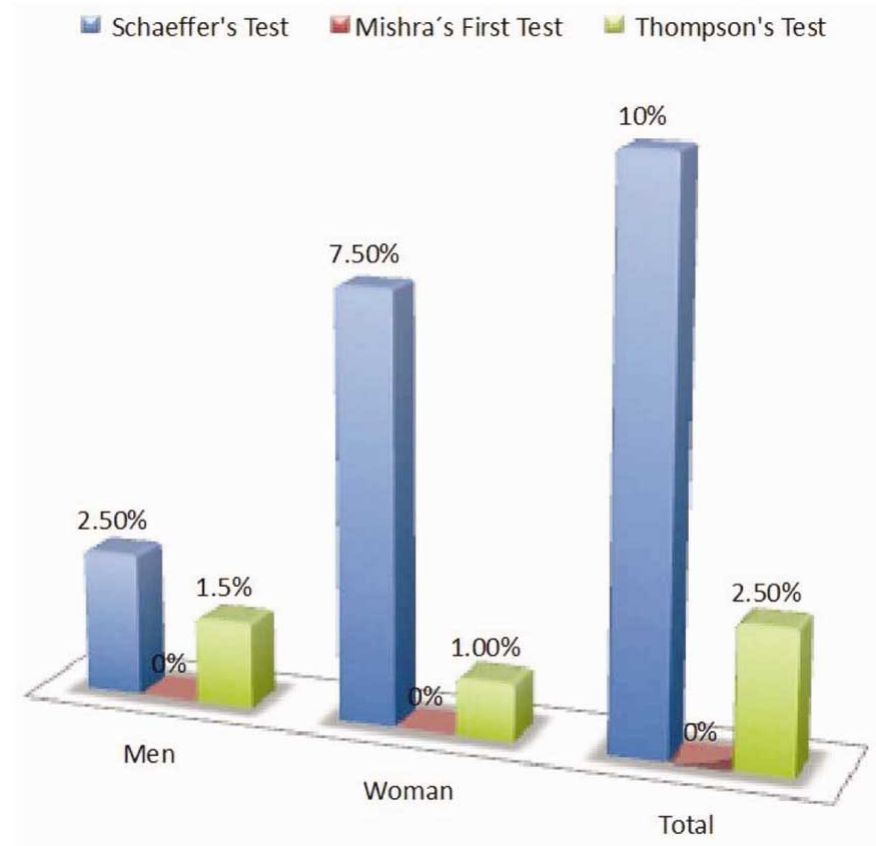

Fig. 5. Percentage of failed tests.
$(11.40 \%)$ presented unilateral agenesis, being $6(5.26 \%)$ on the right side and 7 $(6.14 \%)$ on the left side (Fig. 4).

Regarding the tests to check the presence of the PLM tendon, only the Mishra's first test did not present any kind of failure. It could be observed that in 20 individuals (15 women and 5 men) the Schaeffer test did not show the muscular tendon, however, it could be palpated through the Mishra First Test and/or Thompson Test. The same occurred with the Thompson Test, in which 2 women and 3 men did not show the presence of the muscular tendon, but it could be palpated in the other two tests (Fig. 5).

\section{DISCUSSION}

The literature reports a wide variation in the prevalence of the agenesis in different ethnic groups. When Ceyhan \& Mavt studied the Turk population they found high values of agenesis of the PLM tendon $(63.91 \%)$. In a recent study, also carried out with the Turk, Kose et al. (2009) found $26.5 \%$ of prevalence of the agenesis, despite being a considerable value, it is highly inferior to the one from the first study and much closer to the values found in the Caucasian population (12.8\% - 37.5\%) (Reimann et al.; Thompson et al., 2001; Eric'et al., 2010).

Among the Nigerian, Kayode et al. (2008) found $31.25 \%$ of agenesis, a very high percentage compared to the $6.7 \%$ found by Mbaka \& Ejiwunmi (2009) and $12.6 \%$ found by Enye et al. (2010) among the same population.

In other ethnic groups lower percentages of agenesis could be observed, $3.7 \%$ among the Amazon natives of the South America (Machado \& DiDio, 1967), 4.6\% for the Chinese (Sebastin et al.), 1.5\% for African black (Gangata), $11.5 \%$ in South Africans miscegenated (Ndou et al., 2010) and $36.8 \%$ for the Bahraini population in the Arabian Gulf (Sater et al., 2010). 
Among the Indian population, Kapoor et al. found $17.2 \%$ of total agenesis, a value close to the one found by Agarwal (2010), which was $20.2 \%$ in a recent study with Indians. In our study with Chileans, we found $20 \%$ of total agenesis, a value similar to the one found by Agarwal among the Indian population.

Several authors reported that the unilateral agenesis is significantly more frequent than the bilateral (Thompson et al., 2001; Kayode et al.; Kapoor et al.; Mbaka \& Ejiwunmi; Agarwal; Eric' et al.). In our results we observed that the unilateral agenesis (11\%) was higher than the bilateral (9\%), although there was no significant statistical difference, such condition was also mentioned by Sebastin et al., Ndou et al., and Enye et al. In the studies with the Turk population accomplished by Ceyhan \& Mavt and Kose et al., the frequency of the bilateral agenesis was highly superior to the unilateral.

There is a great controversy in the literature regarding the agenesis symmetry of the muscle related to sex. In our study the unilateral left agenesis in women was more commonly found, however, there was no significant statistical difference. Thompson et al. (2001), Mbaka \& Ejiwunmi and Ndou et al. also reported that the right and left unilateral agenesis were statistically similar in both sexes. Sater $e t a l$. reported that the muscle was absent more often on the left side than the right one.

Regarding the prevalence according to sex, Thompson et al. (2001) reported that there was higher incidence of this agenesis in men. Kapoor et al. and Mbaka \& Ejiwunmi found higher number of agenesis in men. However, there was no significant statistical difference. Kose et al. and Sater et al. claimed that there was a significantly higher number of agenesis in women than in men. In our study there was a higher number of agenesis in women, however, there was no significant statistical difference, as claimed by Ceyhan \& Mavt and Sebastian et al.

Regarding the tests accomplished in order to verify the presence of the PLM tendon, the First Mishra's test was the most accurate one. Both the Schaeffer and the Thompson tests presented some kind of failure. The Schaeffer Test was also imprecise in Kose et al., Mbaka \& Ejiwunmi and Ndou et al. studies.

Thus, we can conclude that the PLM is frequent in the Chilean population, even though agenesis was observed in some cases. Besides, the agenesis, when present, was found mostly in women, and more on the left side, however, when related, sex and agenesis symmetry, we could conclude that there was no significant statistical difference.

ALVES, N.; RAMíREZ, D. \& DEANA, N. F. Estudio de la frecuencia del músculo palmar largo en individuos chilenos. Int. J. Morphol., 29(2):485-489, 2011.

RESUMEN: El músculo palmar largo (MPL), ubicado en la región anterior del antebrazo, es considerado como uno de los músculos más variables del cuerpo humano, siendo su agenesia la variación anatómica más frecuentemente señalada por los investigadores. El objetivo de este estudio fue investigar la frecuencia del tendón del músculo palmar largo en individuos chilenos y verificar la simetría de la agenesia según el sexo. Para ello, analizamos la presencia del tendón del MPL en 200 individuos chilenos, 114 mujeres y 86 hombres. Fueron utilizadas 3 pruebas: Prueba Schaeffer, Primera Prueba de Mishra y Prueba Thompson. Los datos obtenidos fueron registrados y tabulados. Se observó que el $91 \%$ de los sujetos presentaron el tendón del MPL al menos en uno de los antebrazos, mientras que un $80 \%$ lo presentaron en ambos antebrazos. Se observó aún que la agenesia unilateral estuvo presente en un $11 \%$ de los casos (5\% en el lado derecho y $6 \%$ en el lado izquierdo), ya la agenesia bilateral estuvo presente en $9 \%$. Al analizar la presencia (unilateral y bilateral) del tendón del PLM considerando el sexo, se observó en el 82,56\% de los hombres y en el 78,07\% de las mujeres (p>0,05). Se observó que la ausencia del tendón del MPL era más frecuente en mujeres que en hombres, y en el lado izquierdo que en el derecho, no existiendo diferencias estadísticamente significativas ( $p>0,05)$.

PALABRAS CLAVE: Músculo palmar largo; Variación anatómica; Agenesia.

\section{REFERENCES}

Agarwal, P. Absence of the palmaris longus tendon in Indian population. Indian J. Orthop., 44(2):212-25, 2010.

Ceyhan, O. \& Mavt, A. Distribution of agenesis of palmaris longus muscle in 12 to 18 years old age groups. Indian $J$. Med. Sci., 51:156-60, 1997.
Dângelo, J. G. \& Fattini, C. A. Anatomia básica dos sistemas orgânicos: com a descrição dos ossos, junturas, músculos, vasos e nervos. $1^{\mathrm{a}}$ ed. São Paulo, Atheneu, 1983.

Eric, M.; Krivokuc`a, D.; Savovic', S.; Leksan, I. \& Vucinic', N. Prevalence of the palmaris longus through clinical 
evaluation. Surg. Radiol. Anat., 32:357-61, 2010.

Enye, L. A.; Saalu, L. C. \& Osinubi, A. A. The prevalence of agenesis of Palmaris longus muscle amongst students in two Lagos-Based Medical schools. Int. J. Morphol., 28(3):849-54, 2010.

Gangata, H. The clinical surface anatomy anomalies of the palmaris longus muscle in the Black African population of Zimbabwe and a proposed new testing technique. Clin. Anat., 22:230-5, 2009.

Gray, H. \& Goss, C. M. Anatomia. 28 a ed. Rio de Janeiro, Guanabara Koogan, 1977.

Kapoor, S. K.; Tiwari, A.; Kumar, A.; Bhatia, R.; Tantuway, V. \& Kapoor, S. Clinical relevance of palmaris longus agenesis: common anatomical aberration. Anat. Sci. Int., 83(1):45-8, 2008.

Kayode, A. O.; Olamide A. A.; Blessing, I. O. \& Víctor O. U. Incidence of palmaris longus muscle absence in Nigerian population. Int. J. Morphology, 26(2):305-8, 2008.

Kose, O.; Adanir, O.; Cirpar, M.; Kurklu, M. \& Komurcu, M.. The prevalence of absence of the palmaris longus: a study in Turkish population. Arch. Orthop. Trauma Surg., 129:609-11, 2009.

Lippert, L. Cinesiologia Clínica para Fisioterapeutas, incluindo teste para auto-avaliação. 2 Ed: Rio de Janeiro, Ed. Revinter, 1996.

Machado, A. B. \& DiDio, L. J. Frequency of the musculus palmaris longus studied in vivo in some Amazon indians. Am. J. Phys. Anthropol., 27:11-20, 1967.

Mbaka, G. O. \& Ejiwunmi, A. B. Prevalence of palmaris longus absence - a study in the Yoruba population. Ulster Med. J., 78(2):90-3, 2009.

Mishra, S. Alternative tests in demonstrating the presence of the palmaris longus. Indian J. Plastic Surg., 34:12, 2001.

Moore, K. L. \& Agur, A. M. R. Fundamentos de Anatomia Clínica. $1^{\mathrm{a}}$ ed. Rio de Janeiro, Editora Guanabara Koogan, 1996.

Ndou, R.; Gangata, H.; Mitchell, B.; Ngcongo, T. \& Louw, $\mathrm{G}$. The frequency of absence of palmaris longus in a South African population of mixed race. Clin. Anat., 23:437-42, 2010.
Ozeri, E.; Sgarzani, R.; Negosanti, L.; Pizzigallo, A.; Cipriani, R. \& Marchetti, C. "Hammock" reconstruction of fullthickness excised lower lip: a case report. Eur. J. Plast. Surg., 32:327-31, 2009.

Park, I. J.; Kim, H. M.; Lee, S. U.; Lee, J. Y. \& Jeong, C. Opponensplasty using palmaris longus tendon and flexor retinaculum pulley in patients with severe carpal tunnel syndrome. Arch. Orthop. Trauma Surg., 130:829-34, 2010 .

Reimann, A. F.; Daseler, B. H.; Anson, B. J. \& Beaton, L. E. The Palmaris longus muscle and tendon. A study of 1600 extremities. Anat. Rec., 89(4):495-505, 1944.

Sater, M. S.; Dharap, A. S. \& Abu-Hijleh, M. F. The prevalence of absence of the palmaris longus muscle in the Bahraini population. Clin. Anat., 23(8):956-61, 2010.

Schaeffer, J. P. On the variations of the palmaris longus muscle. Anat. Rec., 3:275-8, 1909.

Sebastin, S. J. \& Lim, A. Y. Clinical Assessment of Absence of the Palmaris Longus and its Association With Other Anatomical Anomalies-A Chinese Population Study. Ann. Acad. Med. Singapore, 35(4):249-53, 2006.

Thompson, N. W.; Mockford, B. J. \& Cran, G. W. Absence of the palmaris longus muscle: a population study. Ulster Med. J., 70(1):22-4, 2001.

Thompson, J. W.; McBatts, J. \& Danforth, C. H. Hereditary and racial variations in the musculus palmaris longus. Am. J. Phys. Anthrop., 4:205-18, 1921.

Ueda, K.; Oba, S.; Okada, M.; Hara, M. \& Zen, N. Eyelid reconstruction with a composite radial forearm palmaris longus tendon flap. J. Plast. Reconstr. Aesthet. Surg., 60:256-9, 2007.

Wehbé, M. A. Tendon graft donor sites. J. Hand Surg. Am., 17(6):1130-2, 1992.

\section{Dirección para correspondencia: \\ Dr. Nilton Alves}

Departamento de Ciencias Básicas y Biomédicas. Facultad de Ciencias de la Salud, Universidad de Talca.

Avenida Lircay s/n

Talca

CHILE

\section{E-mail: niltonnalves@yahoo.com.br}

Recibido : 09-12-2010

Aceptado: 28-02-2011 